\title{
Vitamin B3 Measurement
}

National Cancer Institute

\section{Source}

National Cancer Institute. Vitamin B3 Measurement. NCI Thesaurus. Code C74899.

The determination of the amount of Vitamin B3 present in a sample. 